\title{
Hydroxyproline Excretion and Height Velocity in Adolescent Boys
}

\author{
P. A. ZORAB, STEPHANIE CLARK, AILIE HARRISON, and J. R. SEEL \\ From the Department of Paediatrics, Institute of Diseases of the Chest, Brompton Hospital, London
}

\begin{abstract}
Zorab, P. A., Clark, S., Harrison, A., and Seel, J. R. (1970). Archives of Disease in Childhood, 45, 763. Hydroxyproline excretion and height velocity in adolescent boys. The height velocity of 122 boys of 11 to 17 years is compared with their urinary total hydroxyproline excretion and a close relation is shown. The importance of this is discussed in relation to undersized children and to those with scoliosis in whom rapid growth is often associated with increasing curvature of the spine. Poor correlation was found between urinary total hydroxyproline excretion and height, weight, body surface area, and creatinine excretion.
\end{abstract}

The growth of children may be studied by height and weight measurements or by radiographic studies of bone. Though both are useful neither avoids the difficulty that normal variations may be wide, particularly during the adolescent growth 'spurt'.

Measurements of height and weight are easy to make and are of interest for immediate assessment. Reference to centile charts, such as those of Tanner, Whitehouse, and Takaishi (1966) will enable a child to be compared with others of the same age. It is future growth, however, not present height, which is often the physician's main concern. Will the now undersized child grow more rapidly later on ? Predictions of adult height may be made from present height for children from 3 years of age until puberty (Tanner, 1962). At adolescence an assessment of the degree of skeletal maturity present may be made from a radiograph of the wrist. This is an additional help. If tables such as those by Bayley and Pinneau (1952) are used, relating the Greulich and Pyle (1959) skeletal age to percentage of mature height so far achieved, predictions may be made of the expected adult height, which are rather better than those made from present height alone.

Interest has existed for some years in the relation between urinary hydroxyproline excretion and age. This imino acid is found in significant amounts virtually only in body collagen. The daily urinary excretion of endogeneous hydroxyproline therefore provides a useful index of collagen turnover in health and disease (Ziff et al., 1956; Dull, Causing, and Henneman, 1962; Kivirikko and Laitinen, 1965).

Received 5 May 1970.
Younoszai (1967) showed that in infants between 3 and 17 weeks of age there is a direct relation between daily hydroxyproline excretion and the rate of linear growth. Prockop and Kivirikko (1967) showed that the excretion was greater in normal children than in adults. Anderson, Bannister, and Tomlinson (1965) suggested that the highest excretion levels were found in 6 to 10-year-old girls and 11 to 15-year-old boys and that children generally excrete more hydroxyproline than adults. Jones et al. (1964) suggested that peak excretion levels are found in children of 14 and 15 years, and that there is good correlation between hydroxyproline excretion and growth.

In our study of normal children we have examined the relation of total hydroxyproline excretion to height, weight, body surface area, and creatinine excretion. We have found poor correlation in all cases (Table I) but have been impressed by the apparent similarity between the rise and fall of the mean total hydroxyproline excretion and the growth velocity of children of similar age (Tanner, 1962). We now present further evidence that this relationship is very close.

\section{Method}

In October 1967 the urinary total hydroxyproline excretion in 24 hours was estimated for a group of boarding-school boys aged 11 to 18 years at the Royal Hospital School, Ipswich, while on a collagen-free diet (Zorab, 1969). Two years later we returned to this school and studied the height record of 207 boys whose termly measurements had been recorded during the two years before and after the urinary estimation, by the same school staff. We drew the growth curve for each 
TABLE I

Correlation Coefficients for 310 Normal Boys: Total Hydroxyproline (mg./24 hr.)

\begin{tabular}{|c|c|c|c|c|c|c|}
\hline Age (yr.) & Creatinine & Height & Weight & $\begin{array}{c}\text { Body Surface } \\
\text { Area }\end{array}$ & $\begin{array}{c}\text { Log Body } \\
\text { Surface Area }\end{array}$ & $\frac{\text { THP } \times \text { wt. }}{\text { creatinine }}$ \\
\hline $\left.\begin{array}{l}11- \\
12- \\
13- \\
14- \\
15- \\
16- \\
17- \\
18-\end{array}\right\}$ & $\begin{array}{c}0.3993^{\star \star} \\
0.4215^{\star \star} \\
0.4389^{\star \star} \\
0.2772 \\
-0.2131 \\
0.1713 \\
-0.1143\end{array}$ & $\begin{array}{l}0.2751^{\star} \\
0.4862^{\star \star \star} \\
0.3872^{\star \star} \\
0.2736 \\
-0.1864 \\
-0.0301 \\
0.1270\end{array}$ & $\begin{array}{l}0.4520^{\star \star \star} \\
0.3245^{\star \star} \\
0.5404^{\star \star \star} \\
0.1786 \\
-0.2213 \\
-0.3249 \\
-0.0693\end{array}$ & $\begin{array}{l}0.4230^{\star \star} \\
0.4138^{\star \star} \\
0.5083^{\star \star \star} \\
0.2319 \\
-0.2300 \\
-0.2461 \\
-0.0058\end{array}$ & $\begin{array}{c}0.4246^{\star \star} \\
0.4142^{\star \star} \\
0.4518^{\star \star} \\
0 \cdot 1729 \\
-0.3118^{\star} \\
-0.2032 \\
-0.0055\end{array}$ & $\begin{array}{l}0 \cdot 4336^{\star \star} \\
0 \cdot 2036 \\
0 \cdot 3352^{\star} \\
0 \cdot 3581^{\star} \\
0 \cdot 5980^{\star \star \star} \\
0 \cdot 4113^{\star} \\
0 \cdot 6814^{\star \star \star}\end{array}$ \\
\hline
\end{tabular}

Significant at $5 \%$ level $(0.05)^{\star}$; at $1 \%$ level $\star \star$; and at $0.1 \%$ level $\star \star \star$.

of the 122 boys whose peak height velocity (PHV) occurred during this period. This was done by selecting from the records the largest annual height increment and noting when the peak occurred. All boys were measured in January, April, or September of each year, but to avoid seasonal variations only annual increments were subsequently used. The total hydroxyproline excretion levels were recorded at the appropriate time distance from the PHV of each boy (Fig. 1). The PHV was taken as occurring at the end of the year of maximum growth.

We also analysed the mean annual height increment for five groups of 11 to 15-year-old boys, each group having an increased level of hydroxyproline excretion. These levels were then related to growth performance during one year before and two years after the urinary estimation (Fig. 2).

\section{Results}

It will be seen that the curves of mean height velocity and total hydroxyproline excretion are very similar (Fig. 1). Those with the lowest total hydroxyproline excretion are found either two years before or after the peak of their height velocity.

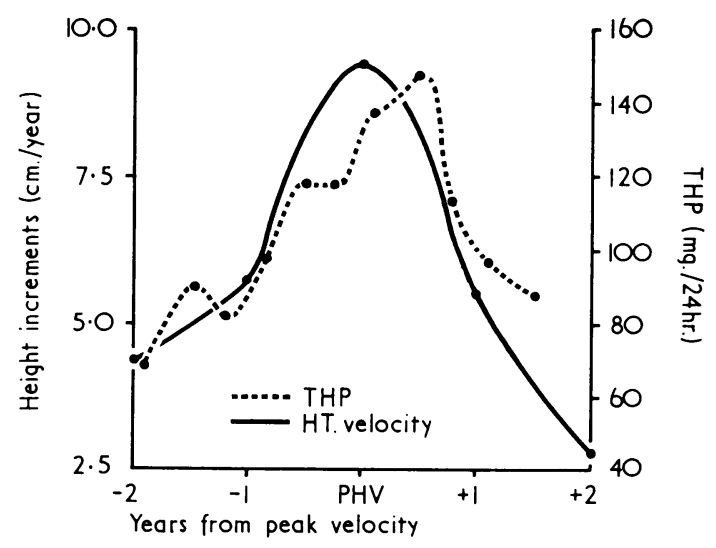

Frg. 1.-Peak height velocity (PHV) and total hydroxyproline (THP) in 122 boys aged 11 to 17 years (means).
Those with the highest levels are found within a few months of their peak velocity. Details are given in Table II.

\section{TABLE II}

Total Hydroxyproline and Height Velocity in Adolescent Boys

\begin{tabular}{|c|c|c|c|c|}
\hline $\begin{array}{l}\text { Years from Peak } \\
\text { Velocity }\end{array}$ & $\begin{array}{l}\text { No. in } \\
\text { Group }\end{array}$ & Mean & SD & SEM \\
\hline & & \multicolumn{3}{|c|}{$\begin{array}{c}\text { Total Hydroxyproline } \\
(\mathrm{mg} . / 24 \mathrm{hr} .)\end{array}$} \\
\hline-1 yr. $11 \mathrm{mth}$. & 29 & $69 \cdot 28$ & $25 \cdot 92$ & $4 \cdot 8$ \\
\hline-1 yr. 6 mth. & 8 & $90 \cdot 75$ & $30 \cdot 66$ & $10 \cdot 8$ \\
\hline-1 yr. 3 mth. & 5 & $83 \cdot 20$ & - & - \\
\hline$-\quad 11 \mathrm{mth}$. & 31 & $98 \cdot 81$ & $35 \cdot 46$ & $6 \cdot 4$ \\
\hline 6 mth. & 8 & $118 \cdot 00$ & $41 \cdot 08$ & $14 \cdot 5$ \\
\hline $3 \mathrm{mth}$. & 3 & $117 \cdot 67$ & - & 一 \\
\hline \multicolumn{5}{|l|}{ Peak Height Velocity } \\
\hline$+\quad 1$ mth. . & 17 & $130 \cdot 12$ & $46 \cdot 82$ & $11 \cdot 4$ \\
\hline 6 mth. . . & 3 & $146 \cdot 67$ & - & - \\
\hline 9 mth. .. & 2 & $113 \cdot 50$ & - & - \\
\hline+1 yr. 1 mth. . & 14 & $96 \cdot 57$ & $17 \cdot 57$ & $4 \cdot 7$ \\
\hline+1 yr. 6 mth. . & 2 & $89 \cdot 00$ & 一 & - \\
\hline & & \multicolumn{3}{|c|}{ Height Gained (cm./yr.) } \\
\hline$-2 \mathrm{yr}$. & 42 & $4 \cdot 47$ & $1 \cdot 12$ & $0 \cdot 17$ \\
\hline-1 yr. $\ldots$ & 94 & $5 \cdot 87$ & $1 \cdot 27$ & $0 \cdot 13$ \\
\hline Peak Height Velocity & 122 & $9 \cdot 50$ & $1 \cdot 02$ & 0.09 \\
\hline+1 yr. $\ldots$ & 74 & $5 \cdot 61$ & $1 \cdot 60$ & $0 \cdot 19$ \\
\hline+2 yr. $\ldots$ & 34 & $2 \cdot 79$ & $1 \cdot 27$ & $0 \cdot 22$ \\
\hline
\end{tabular}

From Fig. 2 it will be seen that groups of boys with a low total hydroxyproline excretion (THP) are seen to have achieved smaller annual height increments than those in which the THP was greater. In other words, low hydroxyproline excretion rates are associated with slow growth and higher rates with more rapid growth. There is no obvious peak of growth velocity in those with low excretion rates.

\section{Discussion}

The results given show that in normal adolescent boys mean growth rates and total hydroxyproline 


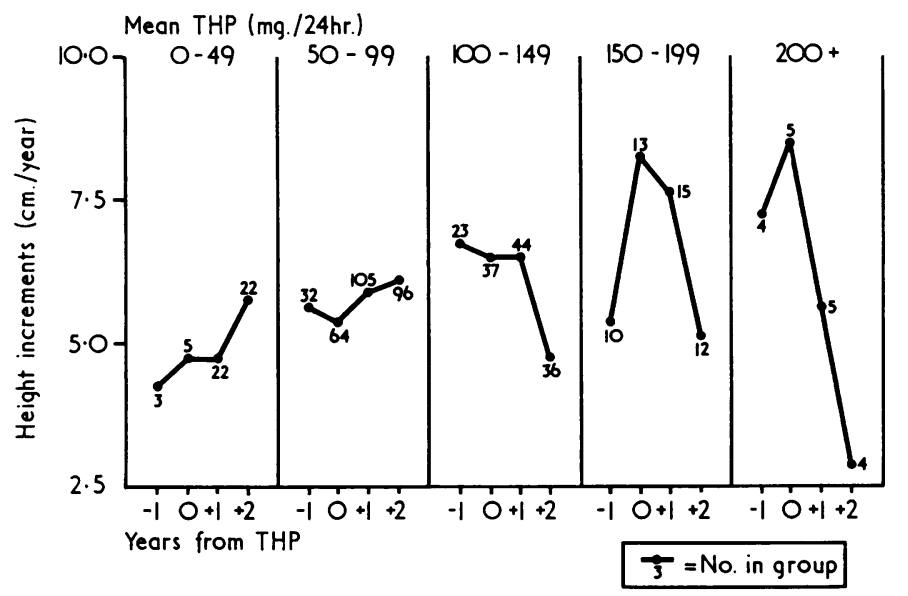

FIG. 2.-Height velocity and THP in boys aged 11 to 15 years.

levels are closely related. From this, two deductions may be drawn. A low excretion rate implies that adolescent growth either has not started or has finished. A high excretion rate implies that growth velocity is high-and that growth will therefore continue, though it may not of course do so at the same rapid rate. If THP estimations are made at intervals of several months, these will suggest whether growth velocity is increasing or diminishing.

It is tempting to use THP excretion rates as a means of predicting further growth. The grounds for doing so are as yet, however, too uncertain to justify their use for this, rather than as a guide to height velocity. Predictions of future growth rates would be of value not only to physicians and others concerned with undersized children, but to those for whom growth itself presents other problems. Among the latter are orthopaedic surgeons caring for children with progressive scoliosis. It is well known that this condition worsens most quickly at times of rapid skeletal growth. A warning that a patient is approaching such a period might considerably influence decisions regarding orthopaedic treatment. Periodic height measurements of scoliotic children are obscured as a guide to growth by the shortening of the spine which scoliosis causes. Periodic estimations of urinary hydroxyproline may be a useful means of learning what point a child has reached in his progress towards maturity.

\section{REFERENCES}

Anderson, J., Bannister, D. W., and Tomlinson, R. W. S. (1965) Total urinary hydroxyproline excretion in normal human subjects. Clinical Science, 29, 583.

Bayley, N., and Pinneau, S. R. (1952). Tables for predicting adult height from skeletal age: revised for use with Greulich-Pyle hand standards. Fournal of Pediatrics, 40, 423.
Dull, T. A., Causing, L., and Henneman, P. H. (1962). Urinary total hydroxyproline as an index of connective tissue turnover in bone. Fournal of Clinical Investigation, 41, 1355.

Greulich, W. W. and Pyle, S. I. (1959). Radiographic Atlas of Skeletal Development of the Hand and Wrist, 2nd ed. p. 51. Stanford University Press, Stanford, California. Oxford University Press, London.

Jones, C. R., Bergman, M. W., Kittner, P. J., and Pigman, W. W. (1964). Urinary hydroxyproline excretion in normal children and adolescents. Proceedings of the Society for Experimental Biology and Medicine, 115, 85.

Kivirikko, K. I. and Laitinen, O. (1965). Clinical significance of urinary hydroxyproline determinations in children. Annales Paediatriae Fenniae, 11, 148.

Prockop, D. J. and Kivirikko, K. I. (1967). Relationship of hydroxyproline excretion in urine to collagen metabolism. Annals of Internal Medicine, 66, 1243.

Tanner, J. M. (1962). The evaluation of growth and maturity in children. In Protein Metabolism: An International Symposium, (Ciba Foundation) p. 361 . Ed. by F. Gross, Springer, Berlin. , Whitehouse, R. H., and Takaishi, M. (1966). Standards from birth to maturity for height, weight, height velocity and weight velocity: British children, 1965. Archives of Disease in Childhood, 41, 454, 613.

Younoszai, M. K. (1967). Urinary excretion of endogenous hydroxyproline by normal male infants. Pediatric Research, 1, 266.

Ziff, M., Kibrick, A., Dresner, E., and Gribetz, H. J. (1956). Excretion of hydroxyproline in patients with rheumatic and non-rheumatic diseases. Fournal of Clinical Investigation, 35, 579.

Zorab, P. A. (1969). Normal creatinine and hydroxyproline excretion in young persons. Lancet, $2,1164$.

We thank Professor J. M. Tanner for advice, and the Headmaster, Mr. A. R. Ellis and the boys of the Royal Hospital School, Ipswich, for their assistance. Financial assistance was given by The Action for the Crippled Child Fund, The Brompton Hospital Research Committee, The Sir Halley Stewart Trust, and The Variety Club of Great Britain.

Correspondence to Dr. P. A. Zorab, Department of Paediatrics, Institute of Diseases of the Chest, Brompton, London S.W.3. 